\author{
Paulina Grenda* (iD) https://orcid.org/0000-0003-2598-2090 \\ Uniwersytecki Szpital Kliniczny w Olsztynie \\ e-mail: grenda.paulina@gmail.com
}

https://doi.org/10.25312/2083-2923.19/2021_04pg

\title{
Nastawienia psychologów i ich wpływ na cechy tworzonych diagnoz
}

\begin{abstract}
Streszczenie: Nastawienia psychologów aktywowane podczas diagnozowania pacjentów nie były do tej pory przedmiotem badań empirycznych. Badane były nastawienia psychoterapeutów wobec danej formy leczenia. Celem przeprowadzonego przeze mnie badania było sprawdzenie, czy cechy diagnoz zależą od aktywacji nastawienia - kategorialnego lub narracyjnego - w jakim znajdowali się badani psycholodzy.

Nastawienia kategorialne i narracyjne badanych psychologów aktywowano za pomocą zadań poznawczych, a cechy formułowanych przez nich diagnoz zostały zbadane przy użyciu metody studium przypadku - symulacji.

Badani psycholodzy pod wpływem aktywacji narracyjnego nastawienia uwzględnili większą liczbę przesłanek diagnostycznych przy uzasadnianiu sformułowanych hipotez niż badani w warunkach eksperymentalnych, w których aktywowano kategorialne nastawienie. Jest to możliwe dzięki temu, że aktywacja nastawienia narracyjnego osłabia stereotypowe myślenie. Wykazano różnice w zakresie liczby hipotez o charakterze nozologicznym formułowanych przez badanych pod wpływem aktywacji nastawienia kategorialnego i narracyjnego.

Słowa kluczowe: diagnoza psychologiczna, nastawienie
\end{abstract}

\section{Wstęp}

Nastawienia psychologów wobec diagnozowanych pacjentów nie były do tej pory przedmiotem badań empirycznych. Tina Zadravec, Onja Grad i Gregor Socan wskazali na postawy odrzucenia i brak wiedzy naukowej jako przyczynę braku efektywności terapii ${ }^{1}$.

* Paulina Grenda - mgr, psycholog, Uniwersytecki Szpital Kliniczny w Olsztynie. Zainteresowania: neuropsychologia, diagnostyka psychologiczna, rehabilitacja neuropsychologiczna.

1 Á. Barth, Z. Demetrovics, G. Bognár, Knowledge of and attitudes toward drug addicts and their treatment among psychiatrists, "Mentálhigiéné és Pszichoszomatika" 2007, Vol. 8(3). 
Murawiec, Jabłoński, Sosnowska, Datka i Moraczewska badali nastawienia 36 psychoterapeutów do leczenia i zidentyfikowali pozytywne nastawienia do łączenia psychoterapii pacjentów z farmakoterapią oraz negatywne - do określonych kategorii pacjentów. Z analizy wynika, że leczenie farmakologiczne i relacja terapeutyczna zależeć może od nastawienia terapeutów do określonych psychoterapii ${ }^{2}$. Nie zbadano do tej pory nastawień psychologów aktywowanych w czasie diagnozowania pacjentów.

Do problematyki roli nastawienia w diagnozie psychologicznej nawiązują badania Efrona i Rabinowitz, którzy wykazali zawodność procesów poznawczych, biorących udział w powstawaniu błędów diagnostycznych i niewłaściwych diagnoz.

Diagnoza psychologiczna jest wynikiem przetwarzania danych diagnostycznych. W związku z tym jest obarczona błędami wynikającymi z zaburzeń przetwarzania poznawczego i wpływem kontekstu społecznego, w którym znajdują się psycholog i jego emocje.

\section{Poznawcze czynniki kształtujące cechy diagnoz formułowanych przez psychologów: od nastawienia do stereotypowego postrzegania pacjentów}

Jeżeli badana osoba jest oceniana i klasyfikowana do różnych kategorii, pojawia się kontrast ${ }^{3}$.

Pod wpływem nasilenia potrzeby domknięcia poznawczego powstają strategie diagnostyczne o charakterze sztywnych zachowań na poziomie procesu poszukiwania i przetwarzania danych. Potrzeba ta służy redukcji poznawczej niepewności przy pomocy schematów poznawczych i stereotypów 4 .

Przez nastawienie rozumie się schematyczne podejście do problemu w taki sposób, w jaki jest on reprezentowany w umyśle przez pryzmat procedury, za pomocą

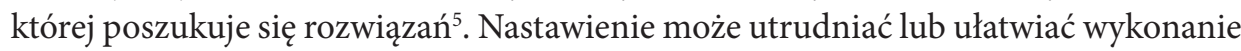
zadania.

Nastawienie stanowi gotowość do reagowania w pewnych sytuacjach, a niereagowania w innych. Oznacza ono przygotowanie do odbioru pewnych określonych bodźców. Nastawienie przejawia się w gotowości dostrzegania pewnych elementów

${ }^{2}$ S. Murawiec, M. Jabłoński, K. Sosnowska, W. Datka, A. Król-Kuczkowska, R. Moraczewska, Nastawienia psychoterapeutek do leczenia farmakologicznego w trakcie prowadzenia psychoterapii badanie pilotażowe w wielkomiejskim ośrodku psychiatryczno-psychoterapeutycznym, „Psychiatria” 2015, nr 3(12).

${ }^{3}$ B. Wojciszke, Człowiek wśród ludzi. Zarys psychologii społecznej, Wydawnictwo Naukowe „Scholar”, Warszawa 2002.

${ }^{4} \mathrm{M}$. Kossowska, Różnice indywidualne w potrzebie poznawczego domknięcia, „Przegląd Psychologiczny" 2003, nr 4(46), s. 12-13.

${ }^{5}$ E. Nęcka, J. Orzechowski, B. Szymura, Psychologia poznawcza, Wydawnictwo Naukowe PWN, Warszawa 2007. 
otaczającego świata i pomijaniu innych. W odróżnieniu od postawy nastawienie cechuje aspekt gotowości do reagowania, a nie emocjonalno-uczuciowe ustosunkowanie do obiektu. Postawy zawierają większą liczbę elementów słabo uświadomionych ${ }^{6}$.

Do zniekształcania informacji i do kształtowania cech diagnoz może się przyczyniać również stereotypizacja. Według Antczak i Trzebińskiego wizja osoby badanej konstruowana jest przez przypisanie jej do określonej kategorii społecznej i przypisanie jej atrybutów przynależnych dla określonej kategorii ${ }^{7}$.

Aby mówić o stereotypizacji, trzeba wyodrębnić kategorie w sposób podzielany społecznie i podtrzymywany społecznie w ramach danej grupy. Stereotypizacja polega na spostrzeganiu osoby jako przedstawiciela określonej kategorii i przypisywaniu jej atrybutów przynależnych tej kategorii. Dostrzeżenie historii życia pacjenta może pozwolić psychologowi na ocenę pacjenta w szerszym kontekście niż w sytuacji, gdy się nie uwzględnia tego kontekstu.

Aktywizacja nastawienia narracyjnego zwiększa udział treści odnoszących się do motywów poznawanej osoby, przy jednoczesnym osłabieniu roli stereotypów ${ }^{8}$.

Trzebiński i Antczak ${ }^{9}$ wykorzystali koncepcję przetwarzania informacji Brunera, zgodnie z którą ludzie przetwarzają informacje w sposób narracyjny, kategorialny i paradygmatyczny. Wyodrębnili analogicznie trzy sposoby konstruowania wizji danej osoby ${ }^{10}$. Psycholog może przetwarzać rzeczywistość na dwa sposoby: w sposób kategorialny i narracyjny. Kategorialne przetwarzanie danych obejmuje racjonalne i złożone rozumowanie oraz bezrefleksyjne i sztywne stosowanie kategorii społecznych. W procesie rozumienia drugiej osoby takie przetwarzanie informacji może prowadzić na przykład do stereotypizacji i uprzedzenia w postrzeganiu drugiej osoby, w podejmowaniu decyzji ${ }^{11}$. To przetwarzanie umożliwia ludziom nieustanne kategoryzowanie obiektów fizycznych, symbolicznych, wyobrażonych, społecznych, w szczególności ludzi. Podstawą kategoryzacji jest tworzenie poznawczej reprezentacji pewnego zbioru obiektów przy pomocy etykiety werbalnej upraszczającej komunikowanie.

„Nastawienie narracyjne służy rozumieniu i zapamiętywaniu rzeczywistości, głównie złożonej z rozciągniętych w czasie faktów. Jest to możliwe dzięki interpretacji za pomocą procedur zawartych w schematach narracyjnych. Narracyjne rozumienie oznacza sposób rozumienia świata przez ludzi poprzez dostrzeganie historii

${ }^{6}$ W. Kozłowski, Nastawienie, [w:] W. Pomykało (red.), Encyklopedia pedagogiczna, Fundacja Innowacja, Warszawa 1993, s. 615.

${ }^{7}$ E. Antczak, J. Trzebiński, Osobista historia i stereotyp jako dwa konteksty poznawania drugiej osoby, [w:] E. Zdankiewicz-Ścigała, T. Maruszewski (red.), Wokół psychomanipulacji, Académica, Warszawa 2006.

8 Tamże, s. 33-38.

9 Tamże, s. 33.

${ }_{10}$ J. Bruner, Actual minds, possible worlds, Harvard University Press, Cambridge 1986; J. Bruner, The narrative construction of reality, "Critical Inquiry" 1991, Vol. 18, No. 1.

${ }^{11}$ E. Antczak, J. Trzebiński, dz. cyt., s. 33-38. 
w obserwowanych wydarzeniach ${ }^{12}$ i uwzględnienie kontekstu w analizowaniu rzeczywistości. Rozumienie narracyjne może być konstruowane również na bazie ogólniejszych niespecyficznych dla przedmiotu interpretacji struktur wiedzy. Nastawienie to jest w małym stopniu oparte na schematach. Nastawienie narracyjne składa się z czterech komponentów schematów. Przede wszystkim kształtuje bohaterów historii dziejących się w danej sferze. Ponadto modeluje ich wartości - pozytywne i negatywne dla bohaterów stany tej sfery. Kształtuje on również ogół głównych intencji tych bohaterów. Nastawienie narracyjne modeluje także możliwe komplikacje czekające bohaterów w momencie realizacji intencji i planów. Dotyczy ponadto uwarunkowań i szans przezwyciężenia trudności i realizacji intencji. Te komponenty tworzą poznawcze przesłanki możliwych wątków historii dziejących się w ramach danej sfery życia jednostki ${ }^{13}$.

Schematyzacja może przyczyniać się do tego, że w problemach rutynowych eksperci wykazują małą elastyczność, bezrefleksyjność, a więc sprzyja automatyzacji ${ }^{14}$.

Badani w omawianym eksperymencie Antczak i Trzebińskiego wykonywali zadania poznawcze, aktywizując nastawienia i zadania diagnostyczne. Aktywacja nastawienia kategorialnego lub narracyjnego spowodowała, że badani zdiagnozowali przypadek przedstawiony w studium przypadku (studium przypadku - symulacja) w inny sposób, co znalazło odzwierciedlenie w liczbie przesłanek diagnostycznych, na których respondenci opierali swoje wnioski. Badani psychologowie w kategorialnym nastawieniu sformułowali diagnozy oparte na mniejszej liczbie przesłanek diagnostycznych niż psycholodzy w stanie doświadczalnym, w którym podniesiono postawę narracyjną.

Celem prezentowanego badania była ocena porównawcza cech diagnoz formułowanych przez psychologów zatrudnionych w różnych instytucjach i prowadzących gabinety poddanych wpływowi aktywacji nastawienia kategorialnego i narracyjnego. Te cechy mogą prowadzić do zniekształcenia choroby psychicznej, zaburzeń psychicznych i ujawnienia różnych charakterystyk diagnoz. Dążono ponadto do sprawdzenia teoretycznego modelu zależności cech diagnostycznych formułowanych przez psychologów od aktywacji nastawienia kategorialnego lub narracyjnego.

Diagnoza psychologiczna powstaje w wyniku przetwarzania danych diagnostycznych. Jej treść i forma zależą od kontekstu społecznego, w jakim znajduje się psycholog ${ }^{15}$.

Zgodnie z ustaleniami Antczak i Trzebińskiego ${ }^{16}$ opartymi na założeniach koncepcji Brunera ${ }^{17}$ aktywizacja nastawienia narracyjnego powinna osłabić stereotypowe

12 J. Trzebiński, Narracja jako sposób rozumienia świata, Gdańskie Wydawnictwo Psychologiczne, Gdańsk 2002.

13 E. Antczak, J. Trzebiński, dz. cyt., s. 33-38.

14 M. Feltovitch, P.E. Johnson, J.H. Moller, D.B. Swabson, 1982, cyt. za: E. Nęcka, J. Orzechowski, B. Szymura, dz. cyt., s. 171.

15 Tamże, s. 171.

16 E. Antczak, J. Trzebiński, dz. cyt., s. 33-38.

17 J. Bruner, Actual minds..., dz. cyt.; J. Bruner, The narrative construction..., dz. cyt. 
myślenie i sprzyjać postrzeganiu osoby mającej swój kontekst społeczny, a nie aktywować postawę kategorialną sprzyjającą stereotypowemu myśleniu i ignorowaniu kontekstu społecznego w postrzeganiu osoby.

Wymaga to redefiniowania problemu jako nowego, co może prowadzić do wytworzenia nowego schematu. Automatycznemu podejmowaniu decyzji sprzyja rutynowe wykonywanie zadań, a temu duży staż pracy ${ }^{18}$.

$\mathrm{Z}$ aktywacją nastawienia kategorialnego wiąże się sztywność myślenia. Choć nie badałam sztywności poznawczej psychologów, to można związki między tymi kategoriami przeanalizować teoretycznie. Przypuszczać można, że brak aktywacji nastawienia narracyjnego może zwiększać sztywność myślenia ${ }^{19}$. Sztywność myślenia powinna powodować, że badani będą formułować mniej hipotez. Jednak wyniki badań nie potwierdziły, że pod wpływem wykonania zadania poznawczego aktywującego nastawienie kategorialne badani formułowali mniejszą liczbę hipotez niż pod wpływem aktywacji nastawienia narracyjnego. Sztywność wynikać może z tego, że psycholodzy mogą mieć trudności z przywoływaniem z pamięci mało istotnych z punktu widzenia określonego problemu danych, pomimo że pacjent mówił o nich. Bowiem aktywizowane pod wpływem wzbudzenia nastawienia kategorialnego schematy kształtują procesy pamięciowe. Wzbudzenie nastawienia narracyjnego, które powinno osłabić sztywne myślenie, nie spowodowało, iż badani formułowali więcej nowych hipotez niż ci, u których wzbudzono nastawienie kategorialne.

Osłabienie sztywności poznawczej powinno spowodować również, że badani będą w większym zakresie uwzględniać kontekst społeczny, diagnozując pacjenta. Wbrew temu, co można było przewidywać zgodnie z podstawowym błędem atrybucji badani w warunku eksperymentalnym, w którym aktywowano nastawienie narracyjne, nie dostrzegali częściej kontekstu społecznego niż badani w warunku, w którym wzbudzano nastawienie kategorialne, i nie uwzględniali czynników sytuacyjnych ${ }^{20}$.

\section{Procedura badań Trzebińskiego i Antczak}

Podstawą opracowania metodologii omawianego w artykule eksperymentu była procedura badawcza oparta na schemacie badania Trzebińskiego i Antczak, którzy zbadali 62 uczniów klas II i III warszawskich liceów metodą indywidualnego badania komputerowego z zastosowaniem programu inquisit pozwalającego na pomiar czasów reakcji. Na wstępie poinformowano badanych, że będą uczestniczyć w dwóch badaniach - nastąpią dwie fazy eksperymentu. Osoby badane przydzielano losowo

18 Tamże, s. 171 .

${ }^{19}$ K. Piber-Dąbrowska, G. Sędak, Spostrzeganie bez uprzedzeń i stereotypów - zarys problematyki, „Psychologia Społeczna” 2006, nr 2(02).

20 P. Grenda, Cechy diagnoz psychologicznych sformułowane przez psychologów w kontekście kategorii a narracja, Praca magisterska pod kierunkiem dr Anny Słysz, Instytut Psychologii Wydziału Nauk Społecznych Uniwersytetu im. Adama Mickiewicza w Poznaniu, Poznań 2017, s. 96-97. 
do jednego z trzech warunków eksperymentalnych. Miały one wykonać zadanie poprzedzające, które miało zaktywizować nastawienie narracyjne, a następnie - zadanie neutralne narracyjnie lub przejść od razu do drugiej fazy. Nastawienie narracyjne aktywowano w ten sposób, że badani konstruowali historie do prezentowanych obrazków. Natomiast nastawienie kategorialne aktywizowane było poprzez kategoryzowanie zawodów o podanych nazwach wraz z utworzoną przez siebie definicją kategorii (czynność neutralna). W następnym etapie analizowano sposób, w jaki badani wnioskowali na temat drugiej osoby. Na podstawie opisu autentycznej osoby badanej testami psychologicznymi badany miał zapoznawać się z charakterystyką postaci bodźcowej pojawiającej się na ekranie monitora, z cechami jej charakteru ${ }^{21}$.

Każdemu badanemu prezentowano jedną z sześciu postaci. Mieli oni także wybrać dziesięć spośród pięćdziesięciu cech, których nazwy mieli podane. Następnie badano, jak zróżnicowanie tła wpływa na poziom stereotypowości utworzonej przez badanego wizji postaci i treść tej wizji. Badanemu prezentowano jedną z trzech wersji danych o cechach osobowości postaci bodźcowej: 1) zgodnych z treścią stereotypu policjanta, 2) niezgodnych z treścią stereotypu policjanta, 3) obojętnych wobec treści stereotypu $^{22}$.

\section{Materiał i metody}

W badaniu posłużyłam się specjalnie skonstruowanym do badania psychologów arkuszem analizy przypadku - symulacji. Arkusz zawierał opis rozmowy psychologa z pacjentem i zadanie sformułowania hipotez diagnostycznych po dodaniu kolejnych informacji dotyczących pacjenta oraz ankietę na temat cech społeczno-demograficznych pacjenta. W kolejnym etapie badani mieli za zadanie zweryfikować własne hipotezy po podaniu najpierw informacji sugerujących dobre przystosowanie społeczne pacjenta, a następnie - danych przemawiających za problemami pacjenta w zakresie przystosowania. Przygotowano arkusz zadania poznawczego w dwóch wersjach w celu podawania go badanym przed wykonaniem zadania diagnostycznego. W każdym zadaniu zawarte było polecenie oszacowania wartości procentowej pewności formułowanych hipotez.

Metoda opiera się na autentycznym opisie przypadku. Zmienione zostały dane, w tym społeczno-demograficzne, aby niemożliwa była identyfikacja opisanej osoby. Opisana osoba nie została formalnie zdiagnozowana.

Badanie zawierało zestaw składający się z dwóch metod: analizy przypadku - symulacji i ankiety. Zadanie badanych sprowadzało się do wykonania zadania poznawczego i sformułowania hipotez diagnostycznych dotyczących omawianego w studium pacjenta po podaniu określonych danych pacjenta. Mieli oni także udzielić odpowiedzi

\footnotetext{
${ }^{21}$ E. Antczak, J. Trzebiński, dz. cyt., s. 33-37.

22 Tamże, s. 33-37.
} 
na pytania dotyczące osoby badanej. Badani psycholodzy zostali też zbadani arkuszem zadania poznawczego i diagnostycznego oraz ankietą zawierającą pytania na temat społeczno-demograficznych charakterystyk badanych. Wykorzystano dwie wersje zadań poznawczych - grupowanie zaburzeń psychicznych i pisanie historii danej osoby - aktywizujących dwa odmienne nastawienia. Narzędzia te zostały skonstruowane przeze mnie w celu przeprowadzenia badania w ramach pracy magisterskiej.

W cytowanych badaniach wykorzystano eksperyment z przydziałem celowym.

Materiał badawczy zebrano za pomocą eksperymentu na grupie 20 psychologów, zatrudnionych w Olsztynie i okolicach Olsztyna w formie indywidualnych spotkań. Kryterium wyboru do badania był staż pracy - co najmniej pięć lat. Badani byli dobierani w taki sposób, aby w próbie była równa liczba osób pod względem pewnych cech, na przykład płci.

\section{Zmienne}

W badaniu wyodrębniono następujący zestaw zmiennych: 1) zmienną zależną główną: cechy diagnoz formułowanych przez psychologów, 2) zmienną zależną uboczną: błędy poznawcze popełniane przez psychologów, 3) zmienną niezależną główną: nastawienia kategorialne, narracyjne, 4) zmienne niezależne uboczne: główne podejście psychoterapeutyczne, staż pracy, wiek badanych.

Nastawienia badanych psychologów były badane za pomocą eksperymentu.

Do grupy eksperymentalnej psychologów wprowadzono manipulację w postaci wykonania przez każdego psychologa zadania poznawczego. Następnie przeprowadzono posttest Y w obu grupach - badani wykonali zadanie diagnostyczne. Eksperyment nie został przeprowadzony zgodnie z zasadą randomizacji, to jest przydzielaniem poszczególnych wartości jednej zmiennej niezależnej - głównej (nastawienia psychologów) w sposób losowy. Miał on więc charakter quasi-eksperymentu. Został wykonany z przydziałem celowym ${ }^{23}$.

Skonstruowałam w taki sposób arkusze zadania poznawczego i arkusz analizy przypadku - symulacji, że porównywane były takie wartości, które mają charakter ilościowy, czyli procent szacowanej pewności, liczba nowych hipotez, łączna liczba hipotez itp. Można więc było analizować je statystycznymi testami dla danych ilościowych, takimi jak test $t$ średnich.

Do próby celowej (eksperckiej) badacze dobierają taką liczbę osób w sposób subiektywny w celu uzyskania próby, która wydaje się reprezentować populację ${ }^{24}$.

${ }^{23}$ P. Grenda, dz. cyt.

${ }^{24}$ E. Babbie, Badania społeczne w praktyce, Wydawnictwo Naukowe PWN, Warszawa 2002, s. 199. 


\section{Wyniki}

Przebadano 20 psychologów: 10 kobiet i 10 mężczyzn. Średni wiek wyniósł 27,2, a średni staż pracy - 23,4 lat. Najmłodsza badana osoba miała 26 lat, a najstarsza - 48 . Większość badanych psychologów to osoby w wieku między 33. a 48. rokiem życia. Najmniej (pięciu) było badanych w przedziale wiekowym 26-31 lat.

Tabela 1. Badani według wieku

\begin{tabular}{|l|c|c|c|c|}
\hline \multicolumn{1}{|c|}{ Wiek } & Częstość & $\%$ & Średnia wieku & Odchylenie \\
\hline $26-31$ & 5 & 25 & & \\
\cline { 1 - 2 } $33-38$ & 7 & 35 & & \multirow{2}{*}{27,2} \\
\cline { 1 - 2 } $41-48$ & 7 & 35 & \\
\cline { 1 - 3 } 49 i więcej & 0 & 0 & & \\
\cline { 1 - 3 } Brak odpowiedzi & 1 & 5 & & \\
\hline
\end{tabular}

Średnia długość doświadczenia zawodowego wynosiła 23,4 lat, a odchylenie standardowe - 9,5. Najmniej było psychologów ze stażem 30-39 lat. Minimalny staż pracy badanych wyniósł pięć lat. W każdej grupie eksperymentalnej było po 10 badanych psychologów.

Tabela 2. Badani psycholodzy według stażu pracy

\begin{tabular}{|c|c|c|c|c|}
\hline Przedział lat & Częstość & $\%$ & Średnia lat stażu & $\begin{array}{l}\text { Odchylenie } \\
\text { standardowe }\end{array}$ \\
\hline $1-9$ & 8 & 40 & \multirow{5}{*}{23,4} & \multirow{5}{*}{9,5} \\
\hline $10-19$ & 8 & 40 & & \\
\hline $20-29$ & 3 & 15 & & \\
\hline $30-39$ & 1 & 5 & & \\
\hline Ogółem & 20 & 100 & & \\
\hline
\end{tabular}

W badanej populacji było pięciu psychologów pracujących w podejściu poznawczo-behawioralnym i pięciu identyfikujących swoją pracę terapeutyczną z paradygmatem psychodynamicznym, dwóch psychologów pracujących w podejściu systemowym oraz czterech psychologów niedeklarujących głównego nurtu, w którym pracują. Jeden psycholog deklarował, iż prowadzi psychoterapię według integracyjnej koncepcji schematów Younga.

Dobór osób do prowadzonych przeze mnie badań był także ograniczony faktem, że badani byli przedstawiciele określonej grupy zawodowej. Niska jest na ogół ich gotowość do wzięcia udziału w badaniu. 
Trzeba pamiętać, że w myśl twierdzenia Haysa badanie jak największej liczby osób może prowadzić do błędów, ponieważ daje podstawy, aby każdą, nawet błahą, zależność uznać za doniosłą teoretycznie ${ }^{25}$.

Przeprowadzono analizę częstości odpowiedzi dla zmiennych mierzonych na skalach nominalnych i ilościowych. Symulację wskazało najmniej osób $(\mathrm{N}=5,8 \%)$. Spośród diagnoz nozologicznych badani najczęściej wymieniali osobowość dysocjacyjną $(\mathrm{N}=4)$, zaburzenie dysocjalne $(\mathrm{N}=3)$ i zaburzenie narcystyczne $(\mathrm{N}=3)$. Spośród wszystkich wymienionych hipotez diagnostycznych było 13 takich, które miały charakter zarówno diagnozy nozologicznej, jak i funkcjonalnej. Odnotowano 15 hipotez nozologicznych i 6 funkcjonalnych.

Tabela 3. Analiza częstości odpowiedzi dotyczących formułowanych hipotez diagnostycznych

\begin{tabular}{|l|c|c|}
\hline \multicolumn{1}{|c|}{ Hipotezy diagnostyczne badanych } & \multicolumn{2}{c|}{ Odpowiedzi } \\
\cline { 2 - 3 } & $\mathrm{N}$ & $\%^{*}$ \\
\hline Zaburzenie nerwicowe & 1 & 3,40 \\
\hline Zaburzenie maniakalno-depresyjne & 2 & 6,90 \\
\hline Zaburzenie narcystyczne & 3 & 11,00 \\
\hline Osobowość dysocjacyjna & 4 & 13,30 \\
\hline Symulacje & 3 & 11,00 \\
\hline Zaburzenie dysocjalne & 3 & 11,00 \\
\hline Tworzenie hipotez diagnostycznych poprzez wskazanie mechanizmu zaburzenia & 13 & 37,10 \\
\hline i jednostki nozologicznej & 1 & 0,03 \\
\hline Nietolerowanie, gdy coś dzieje się nie po jego myśli & 5 & 18,50 \\
\hline Strata kogoś bliskiego & 3 & 8,50 \\
\hline Zbyt mało danych & 3 \\
\hline * Procentów nie sumujemy do 100,0, ponieważ badany mógł sformułować więcej niż jedną hipotezę.
\end{tabular}

Tabela 4. Częstotliwość formułowania nozologicznych hipotez diagnostycznych

\begin{tabular}{|l|l|c|c|c|c|}
\cline { 2 - 5 } \multicolumn{1}{c|}{} & Nastawienie & $\mathrm{N}$ & Średnia & $\begin{array}{c}\text { Odchylenie } \\
\text { standardowe }\end{array}$ & $\begin{array}{c}\text { Błąd standardowy } \\
\text { średniej }\end{array}$ \\
\hline $\begin{array}{l}\text { Częstotliwość formułowania } \\
\text { nozologicznych hipotez } \\
\text { diagnostycznych }\end{array}$ & kategorialne & 10 & 0,6 & 0,5 & 0,2 \\
\cline { 2 - 6 } & narracyjne & 10 & 2,1 & 2,2 & 0,7 \\
\hline
\end{tabular}

Jeśli chodzi o diagnozę funkcjonalną, to spośród odpowiedzi badanych można było wyodrębnić pojawiającą się w arkuszach pięciu osób kategorię „strata kogoś bliskiego". Po podaniu informacji na temat wypadku, w jakim uczestniczył pacjent,

${ }^{25}$ W.L. Hays, Statistics for the social sciences, cyt. za: J. Brzeziński, Metodologia badań psychologicznych, Gdańskie Wydawnictwo Psychologiczne, Gdańsk 2007. 
badani najczęściej wskazywali na zaburzenia organiczne i zaburzenia pamięci (łącznie 9 wskazań).

Czterech badanych uzasadniało zachowanie analizowanego pacjenta lękiem przed samotnością lub bliskością. Łącznie czterech badanych wskazało na zaburzenia z grupy zaburzeń antyspołecznych.

Tabela 5. Rozkład odpowiedzi badanych na polecenie wymienienia hipotez diagnostycznych wyjaśniających sytuację pacjenta po podaniu informacji o zdarzeniu, w jakim uczestniczył pacjent

\begin{tabular}{|c|c|c|c|}
\hline & & $\mathrm{N}$ & $\%^{*}$ \\
\hline \multirow{13}{*}{$\begin{array}{l}\text { Hipotezy } \\
\text { formułowane po } \\
\text { podaniu informacji } \\
\text { o zdarzeniu }\end{array}$} & Symulacje & 2 & 5,8 \\
\hline & Patologiczne obrony & 1 & 2,9 \\
\hline & Alkoholizm, środki odurzające, uzależnienie & 4 & 11,2 \\
\hline & Zaburzenia pamięci & 5 & 14,7 \\
\hline & Zaburzenia organiczne & 4 & 11,7 \\
\hline & Zły na przyjaciółkę, że go opuściła & 1 & 2,9 \\
\hline & $\begin{array}{l}\text { Zaburzenia pamięci spowodowane używaniem substancji } \\
\text { psychoaktywnych }\end{array}$ & 3 & 8,8 \\
\hline & Zaburzenie dysocjacyjne & 1 & 2,9 \\
\hline & Antyspołeczne osobowości & 2 & 5,8 \\
\hline & Lęk przed opuszczeniem, bliskością & 4 & 11,6 \\
\hline & Mechanizmy zaprzeczenia & 1 & 2,9 \\
\hline & Socjopatia & 2 & 5,8 \\
\hline & Zaburzenia osobowości & 1 & 2,9 \\
\hline \multicolumn{2}{|l|}{ Zbyt mało danych } & 2 & 5,8 \\
\hline
\end{tabular}

Na początku testowałam hipotezę numer 1 dotyczącą częstotliwości formułowania hipotez nozologicznych przez badanych $\mathrm{w}$ dwóch warunkach eksperymentalnych. Porównywałam średnią liczbę hipotez nozologicznych formułowanych przez 10 badanych $\mathrm{w}$ warunku aktywacji nastawienia kategorialnego i 10 - w warunku nastawienia narracyjnego.

Na podstawie wyników podanych w tabeli 7 można stwierdzić, że na poziomie istotności statystycznej 0,01 istnieją podstawy do odrzucenia hipotezy zerowej o braku różnic w częstotliwości formułowania hipotez nozologicznych przez osoby badane w dwóch warunkach eksperymentalnych. 
Tabela 6. Wyniki statystyk grup dla testu istotności różnic między częstotliwością formułowania przez badanych psychologów hipotez o charakterze nozologicznym w dwóch warunkach eksperymentalnych

\begin{tabular}{|l|l|c|c|c|c|}
\cline { 2 - 5 } \multicolumn{1}{c|}{} & Nastawienie & $\mathrm{N}$ & Średnia & $\begin{array}{c}\text { Odchylenie } \\
\text { standardowe }\end{array}$ & $\begin{array}{c}\text { Błąd standardowy } \\
\text { średniej }\end{array}$ \\
\hline $\begin{array}{l}\text { Częstotliwość formułowania } \\
\text { hipotez diagnostycznych } \\
\text { o charakterze nozologicznym przez } \\
\text { badanych w dwóch warunkach } \\
\text { eksperymentalnych }\end{array}$ & kategorialne & 10 & 0,6 & 0,5 & 0,2 \\
\cline { 2 - 6 } & narracyjne & 10 & 2,1 & 2,2 & 0,7 \\
\hline
\end{tabular}

Badani psycholodzy pod wpływem aktywacji nastawienia narracyjnego i kategorialnego różnili się pod względem formułowanej liczby hipotez nozologicznych.

\section{Tabela 7. Wyniki statystyk testu $t$ średnich dla prób niezależnych dla częstotliwości formułowania hipotez o charakterze nozologicznym w dwóch warunkach eksperymentalnych}

\begin{tabular}{|l|c|c|c|c|c|c|c|}
\hline \multirow{2}{*}{$\begin{array}{c}\text { Częstotliwość formułowania } \\
\text { przez badanych diagnoz } \\
\text { nozologicznych }\end{array}$} & $\mathrm{T}$ & $\mathrm{Df}$ & $\begin{array}{c}\text { Istotność } \\
\text { (dwustronna) }\end{array}$ & $\begin{array}{c}\text { Różnica } \\
\text { średnich }\end{array}$ & $\begin{array}{c}\text { Błąd stan- } \\
\text { dardowy } \\
\text { różnicy }\end{array}$ & $\begin{array}{c}\text { 95\% przedział } \\
\text { ufności dla różnicy } \\
\text { średnich }\end{array}$ \\
\hline Założono równość wariancji & $-2,1$ & 18,0 & 0,0 & $-1,5$ & 0,7 & $-3,0$ & 0,0 \\
\hline $\begin{array}{l}\text { Nie założono rórna } \\
\text { granica }\end{array}$ & granica \\
\hline wariancji & $-2,1$ & 10,0 & 0,1 & $-1,0$ & 0,1 & $-3,1$ & 0,1 \\
\hline
\end{tabular}

Natomiast pod wpływem aktywacji nastawienia kategorialnego i narracyjnego $(\mathrm{N} 1=10, \mathrm{~N} 2=10)$ odnotowano różnice między częstotliwością formułowania diagnoz funkcjonalnych przez badanych.

Z analizy statystycznej wywnioskowano, że grupa psychologów poddana aktywacji nastawienia narracyjnego $(\mathrm{N} 1=10)$ brała pod uwagę większą liczbę przesłanek diagnostycznych w uzasadnianiu sformułowanych hipotez niż grupa badanych w warunkach eksperymentalnych, w których aktywowano nastawienie kategorialne $(\mathrm{N} 2=10)(p<0,001$, test $t$ dla prób niezależnych).

Tabela 8. Wyniki statystyki dla grup dla testu prób niezależnych dla zmiennych: liczba przesłanek diagnostycznych branych pod uwagę przy formułowaniu hipotez przez badanych w dwóch warunkach eksperymentalnych

\begin{tabular}{|c|l|c|c|c|c|}
\cline { 2 - 5 } \multicolumn{1}{c|}{} & \multicolumn{1}{c|}{$\begin{array}{c}\text { Rodzaj } \\
\text { nastawienia }\end{array}$} & $\mathrm{N}$ & Średnia & $\begin{array}{c}\text { Odchylenie } \\
\text { standardowe }\end{array}$ & $\begin{array}{c}\text { Błąd standardowy } \\
\text { średniej }\end{array}$ \\
\hline Liczba przesłanek diagnostycznych & narracyjne & 10 & 2,8 & 0,6 & 0,2 \\
\cline { 2 - 6 } & kategorialne & 10 & 2,1 & 0,3 & 0,1 \\
\hline
\end{tabular}


Z istotnością statystyczną $p \leq 0,01$ można przyjąć, że aktywacja nastawienia narracyjnego powodowała, iż badani formułowali swoje hipotezy diagnostyczne, opierając się średnio na prawie trzech przesłankach diagnostycznych.

Tabela 9. Wyniki testu prób niezależnych dla zmiennych: liczba przesłanek diagnostycznych branych pod uwagę przy formułowaniu diagnoz przez badanych w dwóch warunkach eksperymentalnych

\begin{tabular}{|c|c|c|c|c|c|c|c|c|}
\hline & & \multicolumn{7}{|c|}{ Test prób niezależnych } \\
\hline & & \multicolumn{2}{|c|}{$\begin{array}{l}\text { Test Levene’a na } \\
\text { równość wariancji }\end{array}$} & \multicolumn{5}{|c|}{ Test $t$ dla równości średnich } \\
\hline & & $\mathrm{F}$ & Istotność & $\mathrm{T}$ & Df & $\begin{array}{c}\text { Istotność } \\
\text { (dwustronna) }\end{array}$ & $\begin{array}{l}\text { Różnica } \\
\text { średnich }\end{array}$ & $\begin{array}{l}\text { Standardowa } \\
\text { różnica błędu }\end{array}$ \\
\hline \multirow{2}{*}{$\begin{array}{l}\text { Liczba } \\
\text { przesłanek } \\
\text { diagnostycz- } \\
\text { nych }\end{array}$} & $\begin{array}{l}\text { Założenie } \\
\text { o równości } \\
\text { wariancji }\end{array}$ & 1,0 & 03 & 3,1 & 18,0 & 0,0 & 0,7 & 0,2 \\
\hline & $\begin{array}{l}\text { Brak założenia } \\
\text { o równości } \\
\text { wariancji }\end{array}$ & & & 3,1 & 13,2 & 0,0 & 0,7 & 0,2 \\
\hline
\end{tabular}

Natomiast aktywacja nastawienia kategorialnego powodowała, że badani formułowali swoje hipotezy diagnostyczne, opierając się średnio na nieco ponad dwóch przesłankach diagnostycznych.

Tabela 10. Wyniki testu post hoc dla testu $\boldsymbol{t}$ prób niezależnych dla zmiennych: liczba przesłanek diagnostycznych branych pod uwagę przy formułowaniu diagnoz przez badanych w dwóch warunkach eksperymentalnych

\begin{tabular}{|l|c|c|c|c|}
\cline { 2 - 5 } \multicolumn{1}{c|}{} & Statystyka & Df1 & Df2 & Istotność \\
\hline Welch $^{*}$ & 9,8 & 1 & 13,2 & 0,008 \\
\hline Brown-Forsythe & 9,8 & 1 & 13,2 & 0,008 \\
\hline$*$ Rozkład asymptotyczny F.
\end{tabular}

Na podstawie tabeli 9 stwierdzono, że badani w dwóch warunkach eksperymentalnych różnią się pod względem liczby hipotez nozologicznych.

Tę samą hipotezę testowano za pomocą testu $t$ średnich dla prób niezależnych, analizując częstotliwość formułowania diagnoz funkcjonalnych w dwóch warunkach eksperymentalnych. Badano różnice w zakresie częstotliwości stosowania diagnozy funkcjonalnej przez 10 psychologów poddanych aktywacji nastawienia narracyjnego i 10 poddanych aktywacji nastawienia kategorialnego. 
Tabela 11. Wyniki statystyk testu $t$ średnich dla prób niezależnych dla częstotliwości formułowania hipotez o charakterze nozologicznym w dwóch warunkach eksperymentalnych

\begin{tabular}{|c|c|c|c|c|c|c|c|c|}
\hline \multirow{3}{*}{$\begin{array}{c}\text { Częstotliwość formułowania } \\
\text { przez badanych diagnoz } \\
\text { funkcjonalnych }\end{array}$} & \multicolumn{8}{|c|}{ Test $t$ równości średnich } \\
\hline & \multirow[t]{2}{*}{$\mathrm{F}$} & \multirow[t]{2}{*}{$\mathrm{T}$} & \multirow[t]{2}{*}{ Df } & \multirow{2}{*}{$\begin{array}{l}\text { Istotność } \\
\text { (dwu- } \\
\text { stronna) }\end{array}$} & \multirow{2}{*}{$\begin{array}{l}\text { Różnica } \\
\text { średnich }\end{array}$} & \multirow{2}{*}{$\begin{array}{l}\text { Błąd stan- } \\
\text { dardowy } \\
\text { różnicy }\end{array}$} & \multicolumn{2}{|c|}{$\begin{array}{c}\text { 95\% przedział } \\
\text { ufności dla różnicy } \\
\text { średnich }\end{array}$} \\
\hline & & & & & & & $\begin{array}{c}\text { Dolna } \\
\text { granica }\end{array}$ & $\begin{array}{c}\text { Górna } \\
\text { granica }\end{array}$ \\
\hline Założono równość wariancji & 5,2 & $-2,1$ & 18,0 & 0,0 & $-1,5$ & 0,7 & $-3,0$ & 0,0 \\
\hline $\begin{array}{l}\text { Nie założono równości } \\
\text { wariancji }\end{array}$ & & $-2,1$ & 10,0 & 0,1 & $-1,5$ & 0,7 & $-3,1$ & 0,1 \\
\hline
\end{tabular}

Następnie testowano, czy liczba formułowanych diagnoz funkcjonalnych zależała od aktywacji nastawienia kategorialnego u 10 badanych i nastawienia narracyjnego u kolejnych 10 psychologów.

Analizując wyniki z tabeli 11, zauważamy, że istnieją podstawy do odrzucenia hipotezy zerowej o braku różnic między częstotliwością formułowania diagnoz funkcjonalnych przez badanych w dwóch warunkach eksperymentalnych.

Tabela 12. Wyniki statystyk grupowych testu $t$ średnich dla prób niezależnych dla częstotliwości formułowania hipotez o charakterze funkcjonalnym w dwóch warunkach eksperymentalnych

\begin{tabular}{|l|l|c|c|c|c|}
\cline { 2 - 6 } \multicolumn{1}{c|}{} & \multicolumn{5}{c|}{ Statystyki dla grup } \\
\cline { 2 - 6 } \multicolumn{1}{c|}{} & Nastawienie & $\mathrm{N}$ & Średnia & $\begin{array}{c}\text { Odchylenie } \\
\text { standardowe }\end{array}$ & $\begin{array}{c}\text { Błąd standardowy } \\
\text { średniej }\end{array}$ \\
\hline $\begin{array}{l}\text { Częstotliwość formułowania } \\
\text { diagnoz funkcjonalnych }\end{array}$ & kategorialne & 10 & 1,7 & 2,0 & 0,7 \\
\cline { 2 - 6 } & narracyjne & 10 & 2,4 & 2,3 & 0,7 \\
\hline
\end{tabular}

Wartość statystyki $\mathrm{F}(>1)$ wskazuje na to, że zróżnicowanie wewnątrzgrupowe jest mniejsze od zróżnicowania międzygrupowego. Poziom istotności statystyki F niższy od zakładanego - 0,05, zatem są podstawy do odrzucenia hipotezy zerowej mówiącej o braku statystycznych różnic w częstotliwości formułowania hipotez o charakterze funkcjonalnym w dwóch warunkach eksperymentalnych. Aktywacja nastawienia kategorialnego i narracyjnego skutkowała zmianą częstotliwością formułowania hipotez funkcjonalnych. 
Tabela 13. Wyniki testu $t$ średnich dla prób niezależnych dla częstotliwości formułowania hipotez o charakterze funkcjonalnym w dwóch warunkach eksperymentalnych

\begin{tabular}{|c|c|c|c|c|c|c|c|c|}
\hline & & \multicolumn{7}{|c|}{ Test $t$ równości średnich } \\
\hline & & \multirow[t]{2}{*}{$\mathrm{T}$} & \multirow{2}{*}{ df } & \multirow{2}{*}{$\begin{array}{c}\text { Istotność } \\
\text { (dwustron- } \\
\text { na) }\end{array}$} & \multirow{2}{*}{$\begin{array}{l}\text { Różnica } \\
\text { średnich }\end{array}$} & \multirow{2}{*}{$\begin{array}{c}\text { Błąd } \\
\text { standardowy } \\
\text { różnicy }\end{array}$} & \multicolumn{2}{|c|}{$\begin{array}{c}\text { 95\% przedział } \\
\text { ufności dla różnicy } \\
\text { średnich }\end{array}$} \\
\hline & & & & & & & $\begin{array}{c}\text { Dolna } \\
\text { granica }\end{array}$ & $\begin{array}{l}\text { Górna } \\
\text { granica }\end{array}$ \\
\hline \multirow{2}{*}{$\begin{array}{l}\text { Częstotliwość } \\
\text { formułowania } \\
\text { diagnoz funk- } \\
\text { cjonalnych }\end{array}$} & $\begin{array}{l}\text { Założono } \\
\text { równość } \\
\text { wariancji }\end{array}$ & $-0,2$ & 17,0 & 0,8 & $-0,2$ & 1,2 & $-2,9$ & 2,4 \\
\hline & $\begin{array}{l}\text { Nie założono } \\
\text { równości } \\
\text { wariancji }\end{array}$ & $-0,2$ & 12,5 & 0,9 & $-0,2$ & 1,3 & $-3,0$ & 2,5 \\
\hline
\end{tabular}

Nie możemy odrzucić hipotezy zerowej o braku różnic między częstością dostrzegania przez badanych kontekstu społecznego przy uzasadnianiu hipotez po podaniu informacji na temat wydarzenia, w jakim uczestniczył pacjent, między badanymi w dwóch warunkach eksperymentalnych $(\mathrm{N} 1=10, \mathrm{~N} 2=10)($ tab. 14).

\section{Dyskusja}

Wyniki omawianego badania mają charakter wstępny. W przyszłości będzie można zbadać cechy diagnoz psychologów pod kątem wpływu poprzednio sformułowanych hipotez diagnostycznych na te obecnie tworzone.

W moich badaniach nie było różnic w liczbie nowych hipotez formułowanych ani w liczbie hipotez formułowanych przez respondentów poddanych aktywacji narracji lub nastawienia kategorycznego. Częściowo przeczy to efektowi świeżości lub pierwszeństwa.

Respondenci byli w stanie w większym stopniu zapamiętać treść arkusza zadań poznawczych, w którym mieli pogrupować zaburzenie, aniżeli respondenci piszący tę historię. Być może na skutek efektu świeżości badani pamiętają treść zadania diagnostycznego i wykonanie go nie zależało od aktywacji nastawienia pod wpływem zadania poznawczego. Istotne było również to, że ćwiczenie „grupowania zaburzeń psychicznych" w ramach zadania poznawczego wymagało od badanych więcej czasu niż zadanie „pisania historii”. Zawartość zadania poznawczego w drugim warunku eksperymentu była bowiem mniejsza niż treść zadania w pierwszym warunku. Mogło to sprzyjać wierniejszemu wspominaniu tej treści niż innych. Ten aspekt nie był jednak kontrolowany doświadczalnie. Być może warto powtórzyć ten eksperyment w przyszłości, biorąc pod uwagę czas przeznaczony przez badanych na wykonanie zadania związanego z czytaniem.

Aktywacja nastawienia kategorialnego lub narracyjnego powodowała, że badani opisywali pacjenta przedstawionego w studium przypadku w inny sposób, co znala- 
zło odzwierciedlenie w liczbie przesłanek diagnostycznych, na których respondenci opierali swoje wnioski. Badani psychologowie w kategorycznej orientacji sformułowali diagnozy oparte na mniejszej liczbie przyczyn diagnostycznych niż psycholodzy przy aktywacji nastawienia narracyjnego.

W warunkach eksperymentalnych, w których powstało nastawienie narracyjne, respondenci wzięli pod uwagę większą liczbę przesłanek diagnostycznych w uzasadnianiu sformułowanych hipotez niż badani w warunkach eksperymentalnych, w których aktywowano nastawienie kategorialne. Jest to możliwe dzięki temu, że aktywacja nastawienia narracyjnego osłabia stereotypowe myślenie. Analogiczne wyniki badania zostały opisane przez Bukowskiego ${ }^{26}$, który pokazał, że trening kognitywny wykorzystujący analityczny tryb przetwarzania informacji (rozpoznawanie neutralnych słów), w przeciwieństwie do stosunku umysłu ludzkiego do klasyfikacji wyrazów, hamuje automatyczną aktywację stereotypowych terminów w zadaniu leksykalnym. Przedstawione hipotetyczne zależności powinny być badane empirycznie.

Oskamp w 1962 roku wykazał, że w miarę dodawania kolejnych informacji o pacjencie trafność diagnoz nie ulegała zmianom ${ }^{27}$. Wykorzystana została prawidłowość wykazana przez Schwarza i Blessa, według której jeśli obiekt jest wieloznaczny, a więc i informacje są ze sobą sprzeczne, to informacja kontekstowa prowadzić będzie do asymilacji. Zatem podanie dodatkowych informacji o osobie badanej mogło doprowadzić do tego, że badani włączali podane dane w istniejące struktury poznawcze, co prowadziło do tego, że pomimo małej liczby danych i małej ich precyzyjności badani mogli budować dość precyzyjne konkretne hipotezy diagnostyczne.

Badania nie potwierdziły zależności częstotliwości dostrzegania kontekstu przy uzasadniania hipotez przez psychologów poddanych aktywacji nastawienia narracyjnego. Być może opisana w historii w zadaniu poznawczym kobieta była zbyt mało wyrazista i badani w małym stopniu zapamiętali tę historię, przez co nie doszło do aktywacji wiedzy doświadczeniowej, która sprzyja analizowaniu emocji i motywów u spostrzeganej osoby.

Do ludzi dociera wiele bardzo powierzchownych informacji - trudnych do weryfikacji, co może prowadzić do popełniania błędu konfirmacji, czyli wyszukiwania informacji, które potwierdzają nasze wstępne przekonania ${ }^{28}$. W konsekwencji nie uwzględnia się w diagnozowaniu kontekstu społecznego.

Uwarunkowania tworzenia diagnoz można próbować wyjaśnić poprzez pogłębioną analizę procesów uwagowych i pamięciowych, badanych w trakcie wykonywania

${ }^{26}$ M. Bukowski, Kontekst i stereotypy: ograniczanie aktywacji stereotypów poprzez szkolenie $z$ przetwarzania informacji analitycznych, „Psychologia Społeczna” 2006, $\mathrm{nr}$ 2(02).

27 S. Oskamp, Overconfidence in case-study judgments, "Journal of Consulting Psychology", No. 29(3).

${ }^{28}$ S. Plous, Psychological Mechanisms in the Human Use of Animals, cyt. za: P. Grenda, dz. cyt., s. 17 . 
zadania diagnostycznego, oraz atrybucyjnych i heurystycznych. Badani mogli bowiem stosować heurystykę afektywną, dlatego przecenili tę informację.

Można by zbadać również, czy cechy diagnoz konstruowanych przez psychologów zależą od poziomu sprawności czytania (na przykład w aspekcie rozumienia tekstu lub szybkości czytania).

Nie zwracałam się z prośbą o wyrażenie zgody na prowadzenie badań do Komisji Etycznej Uniwersytetu im. Adama Mickiewicza, ponieważ badani znali ogólny cel moich badań przed wyrażeniem zgody na udział w nich. W badaniu zadbano o to, by nie dochodziło do zniekształceń wyników testu, zgodnie z ideą instrukcji maskujących. Moje badanie nie zawierało wątpliwości etycznych, które powinny zostać poddane przeglądowi przez Komisję. Uczestnictwo w badaniu polegającym na wykonywaniu zadania poznawczego i diagnostycznego nie wiązało się z ryzykiem krzywd psychologicznych i społecznych ani z naruszeniem prywatności. Podczas przeprowadzania eksperymentu zastosowałam wszystkie zasady wymagane przez Komisję, takie jak poufność i anonimowość. Osoby badane wyraziły pisemną zgodę na udział w badaniu ${ }^{29}$.

\section{Wnioski końcowe}

Włączenie do badań nad nastawieniami dodatkowych zmiennych, to jest charakterystyk poznawczych - sztywności poznawczej - umożliwi poznanie psychologicznej podatności psychologów na aktywację nastawienia przy formułowaniu diagnoz. Badanie cech diagnoz psychologicznych przy aktywowaniu nastawienia paradygmatycznego umożliwi poznanie stopnia, w jakim badani pomijali cechy indywidualne pacjenta przy formułowaniu diagnoz ${ }^{30}$.

\section{Implikacje praktyczne}

Otrzymane w pracy wyniki mogą stanowić perspektywę teoretyczną dla opracowywania programów edukacyjnych dla psychologów i pedagogów - naukowców i praktyków w zakresie diagnozy psychologicznej i psychoterapii.

Skonstruowane w pracy narzędzia mogą być używane w celu oceny podatności psychologów, pedagogów na aktywację nastawienia, gdy przed diagnozowaniem wykonują oni zadania poznawcze. Narzędzia te można ponadto wykorzystać w neuropsychologicznych eksperymentalno-klinicznych badaniach dzieci i dorosłych w szpitalach i poradniach.

${ }^{29}$ Zarządzenie nr 180/2013/2014 Rektora UAM z dnia 3 lutego 2014 r. w sprawie wprowadzenia Regulaminu Komisji Etycznej UAM ds. badań naukowych prowadzonych z udziałem ludzi.

${ }^{30}$ P. Grenda, dz. cyt., s. 87. 


\section{Bibliografia}

Antczak E., Trzebiński J., Osobista historia i stereotyp jako dwa konteksty poznawania drugiej osoby, [w:] E. Zdankiewicz-Ścigała, T. Maruszewski (red.), Wokół psychomanipulacji, Académica, Warszawa 2006.

Babbie E. Badania społeczne w praktyce, Wydawnictwo Naukowe PWN, Warszawa 2002.

Barth Á., Demetrovics Z., Bognár G., Knowledge of and attitudes toward drug addicts and their treatment among psychiatrists, "Mentálhigiéné és Pszichoszomatika" 2007, Vol. 8(3).

Bruner J., Actual minds, possible worlds, Harvard University Press, Cambridge 1986.

Bruner J., The narrative construction of reality, "Critical Inquiry” 1991, Vol. 18, No. 1.

Brzeziński J., Metodologia badań psychologicznych, Gdańskie Wydawnictwo Psychologiczne, Gdańsk 2007.

Bukowski M., Kontekst $i$ stereotypy: ograniczanie aktywacji stereotypów poprzez szkolenie z przetwarzania informacji analitycznych, „Psychologia Społeczna” 2006, nr 2(02).

Efron D., Rabinowitz J., Diagnosis, Dogmatism and Rationality, "Journal of Mental Health Counselling” 1997, No. 19(1).

Grenda P., Cechy diagnoz psychologicznych sformułowane przez psychologów w kontekście kategorii a narracja, Praca magisterska pod kierunkiem dr Anny Słysz, Instytut Psychologii Wydziału Nauk Społecznych Uniwersytetu im. Adama Mickiewicza w Poznaniu, Poznań 2017.

Kossowska M., Różnice indywidualne w potrzebie poznawczego domknięcia, „Przegląd Psychologiczny" 2003, nr 4(46).

Kozłowski W., Nastawienie, [w:] W. Pomykało (red.), Encyklopedia pedagogiczna, Fundacja Innowacja, Warszawa 1993.

Murawiec S., Jabłoński M., Sosnowska K., Datka W., Król-Kuczkowska A., Moraczewska R., Nastawienia psychoterapeutek do leczenia farmakologicznego $w$ trakcie prowadzenia psychoterapii - badanie pilotażowe $w$ wielkomiejskim ośrodku psychiatryczno-psychoterapeutycznym, „Psychiatria” 2015, nr 3(12).

Nęcka E., Orzechowski J., Szymura B., Psychologia poznawcza, Wydawnictwo Naukowe PWN, Warszawa 2007.

Oskamp S., Overconfidence in case-study judgments, "Journal of Consulting Psychology", No. 29(3).

Pasikowski T., Sęk H., Psychologiczna diagnoza kliniczna - etapy postępowania diagnostycznego a wynik diagnozy, [w:] H. Sęk (red.), Psychologia kliniczna, t. 1, PWN, Warszawa 2008.

Piber-Dąbrowska K., Sędak G., Spostrzeganie bez uprzedzeń i stereotypów - zarys problematyki, „Psychologia Społeczna” 2006, nr 2(02).

Trzebiński J., Narracja jako sposób rozumienia świata, Gdańskie Wydawnictwo Psychologiczne, Gdańsk 2002. 
Wojciszke B., Człowiek wśród ludzi. Zarys psychologii społecznej, Wydawnictwo Naukowe „Scholar”, Warszawa 2002.

Zarządzenie nr 180/2013/2014 Rektora UAM z dnia 3 lutego 2014 r. w sprawie wprowadzenia Regulaminu Komisji Etycznej UAM ds. badań naukowych prowadzonych z udziałem ludzi.

\section{Psychologists' attitudes and their influence on the characteristics of diagnoses}

Abstract: Psychologists' attitudes activated when diagnosing patients have not so far been subject to empirical research. What has been studied are the attitudes of psychotherapists towards a given form of treatment. The aim of my study was to examine whether the characteristics of diagnoses depend on the activation of an attitude - categorical or narrative - of the psychologists surveyed.

The categorical and narrative attitudes of the psychologists under study were activated using cognitive tasks, and the features of the diagnoses they formulated were examined using the case study-simulation method.

The studied psychologists under the influence of the activation of the narrative attitude took into account a greater number of diagnostic premises when justifying the formulated hypotheses than the studied psychologists in experimental conditions, in which the categorical attitude was activated. This is because activation of the narrative mindset weakens stereotypical thinking. Differences were shown in the number of hypotheses of a nosological nature formulated by the subjects under the influence of activation of the categorical and narrative attitudes.

Keywords: psychological diagnosis, attitude, context

\section{About the Author}

Paulina Grenda - M.A.; psychologist; Uniwersytecki Szpital Kliniczny in Olsztyn (University Clinical Hospital in Olsztyn). Interests: neuropsychology, psychological diagnostics, neuropsychological rehabilitation. 